University of Nebraska - Lincoln

DigitalCommons@University of Nebraska - Lincoln

Papers in Veterinary and Biomedical Science

Veterinary and Biomedical Sciences,

Department of

Spring 2019

\title{
Transposon Mutagenesis in Mycobacterium avium Subspecies Paratuberculosis
}

John P. Bannantine

USDA-ARS-National Animal Disease Center, john.bannantine@usda.gov

Denise K. Zinniel

University of Nebraska - Lincoln, dzinniel2@unl.edu

Raul G. Barletta

University of Nebraska - Lincoln, rbarletta1@unl.edu

Follow this and additional works at: https://digitalcommons.unl.edu/vetscipapers

Part of the Biochemistry, Biophysics, and Structural Biology Commons, Cell and Developmental Biology Commons, Immunology and Infectious Disease Commons, Medical Sciences Commons, Veterinary Microbiology and Immunobiology Commons, and the Veterinary Pathology and Pathobiology Commons

Bannantine, John P.; Zinniel, Denise K.; and Barletta, Raul G., "Transposon Mutagenesis in Mycobacterium avium Subspecies Paratuberculosis" (2019). Papers in Veterinary and Biomedical Science. 341.

https://digitalcommons.unl.edu/vetscipapers/341

This Article is brought to you for free and open access by the Veterinary and Biomedical Sciences, Department of at DigitalCommons@University of Nebraska - Lincoln. It has been accepted for inclusion in Papers in Veterinary and Biomedical Science by an authorized administrator of DigitalCommons@University of Nebraska - Lincoln. 


\section{Chapter 11}

\section{Transposon Mutagenesis in Mycobacterium avium Subspecies Paratuberculosis}

\section{John P. Bannantine, Denise K. Zinniel, and Raúl G. Barletta}

J.P. Bannantine: USDA-ARS-National Animal Disease Center, Ames, IA

D.K. Zinniel \& R.G. Barletta: School of Veterinary Medicine and Biomedical Sciences,University of Nebraska-Lincoln Abstract

While transposon mutagenesis has been developed for Mycobacterium avium subspecies paratuberculosis $(M a p)$, relatively few laboratories have adopted this important genetic tool to examine gene function and essentiality. Here we describe the construction of a Map transposon library using the Himarl mariner transposon, but concepts can also be applied to the Tn 5367 transposon, which has also been used by our group. Delivery of the transposon is by a temperature-sensitive phagemid, $\phi$ MycoMarT7, and plating transductants requires patience and specialized media due to length of incubation required to observe colonies. Several transposon mutants obtained from these libraries have been tested in vaccine and pathogenesis studies. By providing the following detailed protocol herein, we expect to demystify the procedure and encourage additional investigators to incorporate transposon mutagenesis in their studies on Johne's disease.

Key words Transposon mutagenesis, Mycobacterium, Johne's disease

1 Introduction

Mycobacterium avium subspecies paratuberculosis (Map) causes Johne's disease in cattle, sheep, goats, and other ruminants. It is among the slowest growing mycobacteria with a generation time of approximately $24 \mathrm{~h}$ and some strains, especially those isolated from sheep, are difficult to culture. These factors have combined to delay advancements in genetic studies of Map relative to other mycobacteria including M. smegmatis and M. tuberculosis, especially as it relates to vaccine strain construction and essential gene analysis.

The first efforts to genetically modify Map came with the discovery that mycobacteriophage TM4 could form plaques on Map lawns [1]. Soon after, a TM4 derivative, phAE94, was engineered to deliver the Tn5367 transposon randomly into the Map genome [2]. Tn5367 is derived from IS 1096 from M. smegmatis [3]. With this technology in hand, a library of over 5000 transposon mutants was initially constructed [2], and later, 13,500 Tn5367 
mutants of Map were obtained [4]. Directed knockouts using insertion sequences have now also been achieved in Map. Examples of genes that have been targeted using this method include sigH [5, 6], lipN [5], leuD [7], $\operatorname{rel} A, \operatorname{ls} r 2$, and $p k n G$ [8], with $\operatorname{rel} A$ [9] and leuD [10] mutants showing protection from Map challenge in goats.

More recently, our group compared the total genome insertions sites for the mycobacterial transposon Tn5367 with the mariner transposon MycoMarT7 carrying the Himarl transposase [11]. The dinucleotide insertion recognition site $\left(5^{\prime}-\mathrm{TA}-3^{\prime}\right)$ for MycoMarT7 was significantly more prevalent than the degenerate tetramer $\left(5^{\prime}-\mathrm{NNPy}[\mathrm{A} / \mathrm{T}] \mathrm{A}[\mathrm{A} / \mathrm{T}] \mathrm{NN}-3^{\prime}\right)$ Tn 5367 recognition sites such that only 37 genes do not contain a MycoMarT7 site, compared to 710 genes missing Tn5367 sites. Therefore, transposons containing the IS 1096 element have recognition site distribution biases that could affect the interpretation of gene essentiality on a whole genome basis. Nonetheless, this transposon has been useful for single gene studies and mutant library selection under defined conditions $[4,12-15]$.

Tn5367 carries a kanamycin-resistance marker and can be delivered to Map by a thermosensitive phagemid phAE94 derived from mycobacteriophage TM4 [1, 16]. Whereas, MycoMarT7 is a Himarl-derived transposon that also carries a kanamycinresistance marker engineered into the same TM4 phagemid, designated $\phi$ MycoMarT7 [17, 18]. Here we describe the detailed protocols for obtaining a Himarl transposon library in Map.

\section{Materials}

For transposon mutagenesis, the only two strains of Map used thus far are the type strain (ATCC19698) and the bovine clinical isolate K-10. Other Map stains are expected to be amendable to the genetic manipulations described here, although ovine isolates will be more fastidious to grow in the laboratory [19].

1. Middlebrook 7H9 medium: Dissolve $4.7 \mathrm{~g}$ of Difco $^{\text {TM }} 271310$ Middlebrook 7H9 powder (Becton, Dickinson and Company) in $900 \mathrm{ml}$ distilled $\mathrm{H}_{2} \mathrm{O}$ and $2 \mathrm{ml}$ of glycerol. For $\mathrm{Map}$, use $\mathrm{HCl}$ to adjust the $\mathrm{pH}$ to 5.9. If preparing culture media for petri dish applications, microbiological agar $(15 \mathrm{~g} / \mathrm{l})$ is added. Autoclave at $121{ }^{\circ} \mathrm{C}$ for $20 \mathrm{~min}$ with slow exhaust. Cool to $50{ }^{\circ} \mathrm{C}$ (see Note 1 ) in order to add supplements (e.g., Tween ${ }^{\mathrm{TM}}$ 80 , cycloheximide, albumin-dextrose-catalase (ADC; BBL ${ }^{\mathrm{TM}}$ Middlebrook 212352; Becton, Dickinson and Company), oleic acid-albumin-dextrose-catalase (OADC; BBL ${ }^{\text {TM }}$ Middlebrook 212240; Becton, Dickinson and Company), mycobactin J (Allied Monitor, Inc.)) and any desired antibiotic(s) for 
selection. Under sterile conditions, add $2.5 \mathrm{ml}$ of $20 \%$ Tween $^{\mathrm{TM}}$ $80,10 \mathrm{ml}$ of $1 \%$ cycloheximide and $100 \mathrm{ml}$ of ADC (M. smegmatis). For Map, add $2.5 \mathrm{ml}$ of $20 \%$ Tween $^{\mathrm{TM}} 80,10 \mathrm{ml}$ of $1 \%$ cycloheximide, $1 \mathrm{mg}$ of mycobactin $\mathrm{J}$, and $100 \mathrm{ml}$ of OADC instead of ADC. Tween ${ }^{\mathrm{TM}} 80$ is not added if preparing agar $($ see Note 2).

2. Middlebrook $7 \mathrm{H} 10$ agar medium: Dissolve $19 \mathrm{~g}$ of $\mathrm{Difco}^{\mathrm{TM}}$ 262710 Middlebrook $7 \mathrm{Hl} 0$ powder (Becton, Dickinson and Company) in $900 \mathrm{ml}$ distilled $\mathrm{H}_{2} \mathrm{O}$ and $5 \mathrm{ml}$ of glycerol. Autoclave at $121{ }^{\circ} \mathrm{C}$ for $20 \mathrm{~min}$ with slow exhaust. Cool to $50{ }^{\circ} \mathrm{C}$ and add supplements and/or antibiotic(s) as listed above (see Subheading 2, item 1).

3. Mycobacterial phage (MP) buffer: For M. smegmatis, the standard composition is $50 \mathrm{mM}$ Tris- $\mathrm{HCl}, \mathrm{pH} 7.5 ; 150 \mathrm{mM} \mathrm{NaCl}$; $10 \mathrm{mM} \mathrm{MgSO} 4 \cdot 7 \mathrm{H}_{2} \mathrm{O}$; and $2 \mathrm{mM} \mathrm{CaCl}_{2}$. For Map, the components are $50 \mathrm{mM}$ Tris- $\mathrm{HCl}, \mathrm{pH} 7.6 ; 150 \mathrm{mM} \mathrm{NaCl} ; 10 \mathrm{mM}$ $\mathrm{MgCl}_{2}$; and $2 \mathrm{mM} \mathrm{CaCl}_{2}$. These both can be stored up to 1 year at room temperature.

4. Phage soft agar: media is prepared as stated above (see Subheading 2 , item 1 or 2 ) depending on the bacterial source except that $7 \mathrm{~g} / \mathrm{l}$ of microbiological agar is added.

5. Adsorption-stop buffer: MP buffer containing $20 \mathrm{mM}$ sodium citrate and $0.2 \%$ Tween $^{\mathrm{TM}} 80$. This solution is added to prevent further phage infections after completion of the adsorption time.

6. $50 \%$ glycerol-PBS freezing solution: $2 \mathrm{mM} \mathrm{NaH}_{2} \mathrm{PO}_{4}, 4 \mathrm{mM}$ $\mathrm{Na}_{2} \mathrm{HPO}_{4}, 4 \mathrm{mM} \mathrm{NaCl}$, and 50\% glycerol (vol/vol).

\section{Methods}

\subsection{Mycobacterial Culture}

1. Inoculate a 2-1 flask containing $500 \mathrm{ml}$ of Middlebrook $7 \mathrm{H} 9$ at pH 5.9 supplemented with $0.2 \%$ glycerol, OADC, $0.05 \%$ Tween $^{\mathrm{TM}} 80,1 \mathrm{mg}$ mycobactin $\mathrm{J}$ and $0.01 \%$ cycloheximide (see Subheading 2, item 1). Use a single, well isolated colony of the Map strain of choice for the inoculum.

2. Incubate culture stagnant for 4 weeks checking optical density at 540 nanometers (O.D. 540nm) after the third and fourth week.

3. Harvest $50-\mathrm{ml}$ aliquots of cultures in mid-log phase (O.D.540 nm $=0.4$ to 0.75 ) by centrifugation at $4420 \times g$ for $25 \mathrm{~min}$. This optical density equates to approximately $2.0 \times 10^{8} \mathrm{cfu} / \mathrm{ml}$.

4. If preparing a fresh stock of the phagemid, start the phagemid preparation protocol (Subheading 3.2) during the fourth week of growing the Map culture. 


\subsection{Phagemid Preparation}

The phagemid $\phi$ MycoMarT7 must be propagated and titered using freshly grown M. smegmatis cells at $30^{\circ} \mathrm{C}$.

1. Grow approximately $10 \mathrm{ml}$ of $M$. smegmatis $\mathrm{mc}^{2} 155$ shaking overnight at $37^{\circ} \mathrm{C}$ in Middlebrook $7 \mathrm{H} 9$ media supplemented with $0.2 \%$ glycerol, ADC, $0.05 \%$ Tween $^{\mathrm{TM}} 80$ and $0.01 \%$ cycloheximide (see Subheading 2, item 1).

2. From a known $\phi$ MycoMarT7 titer number, make appropriate dilutions in MP buffer. For example, phagemid at a titer of $10^{10}$ plaque-forming units (PFU)/ml will usually have a "lace" pattern (plaques are touching) at $10^{-6}$ that is used for propagation and countable plaques are determined at the $10^{-8}$ dilution. The final dilution should be made several times depending on how much phage needs to be propagated (see Note 3 ).

3. Mix the $M$. smegmatis $\mathrm{mc}^{2} 155$ culture with the phagemid dilution in a 2:1 volume ratio (e.g., $2 \mathrm{ml}$ of culture with $1 \mathrm{ml}$ diluted phagemid).

4. Incubate standing at $30^{\circ} \mathrm{C}$ for $30 \mathrm{~min}$ to allow for adsorption.

5. Add $300 \mu \mathrm{l}$ of the phagemid-cell mixture to $3.5 \mathrm{ml}$ of phage soft agar (see Subheading 2, item 4 ) and gently mix by rolling the tube with your palms. It is important to keep the phage soft agar at $56{ }^{\circ} \mathrm{C}$ until ready to use in a glass tube in a heat block.

6. Pour each tube of phage soft agar containing phagemid-cell mixture onto separate Middlebrook 7H9 agar plates (see Note 4). Quickly rotate the plate in a circular motion to evenly spread the agar over the entire surface. Once solidified, invert the plates to prevent condensation.

7. Incubate at $30{ }^{\circ} \mathrm{C}$ overnight or until plaques are visible (2-3 days).

8. Once plaques are produced and clearly visible, flood each plate with $5 \mathrm{ml}$ of MP buffer. These plates are then incubated at $4{ }^{\circ} \mathrm{C}$ for $2-4 \mathrm{~h}$ followed by incubation at $37{ }^{\circ} \mathrm{C}$ for $\mathrm{l}-2 \mathrm{~h}$ ( see Note 5).

9. Collect the liquid from each plate by pipetting or scraping the top agar off with an L-spreader and pooling in an Oak Ridge centrifuge tube. It is important to use as little buffer as possible so as to not dilute the new stock.

10. Centrifuge for $30 \mathrm{~min}$ at $23,300 \times g$ at $4{ }^{\circ} \mathrm{C}$ to remove agar pieces and bacterial debris. The phagemid stock should now be clarified.

11. Filter phage stock with a $0.45 \mu \mathrm{m}$ filter and store at $4{ }^{\circ} \mathrm{C}$ (crude phage stock). To further purify the crude phage stock, if needed, ultracentrifuge at $82,705 \times g$ for $6 \mathrm{~h}$ at $4{ }^{\circ} \mathrm{C}$ using a SW28 rotor. Dissolve pellet in MP buffer $200 \mu \mathrm{l}$ and wash with 50-100 $\mu$ l of $2 \times$ MP buffer (see Note 6). 
12. Titer new phage stock to determine its concentration (see Note 7 ). This is done by plating phagemid dilutions on $M$. smegmatis cells. Ideally, the titer should be at least $1 \times 10^{10}$ PFU per $\mathrm{ml}$ or better.

\subsection{Transductions}

A schematic representation of the entire transduction and collection procedure encompassing Subheadings 3.3-3.5 are depicted in Fig. 1.

1. Add $1 \mathrm{ml}$ of MP buffer to the Map bacteria concentrated from step 3 of Subheading 3.1.

2. Infect $\operatorname{Map}\left(1.0 \times 10^{7} \mathrm{CFU}\right.$ in $\left.0.1 \mathrm{ml}\right)$ with $0.1 \mathrm{ml}$ of $\varphi$ MycoMarT7 at $1.0 \times 10^{8} \mathrm{PFU}($ see Note 8 ) to have a multiplicity of 10 PFU per bacterium, based on the phage titer determined at the permissive temperature for propagation $\left(30{ }^{\circ} \mathrm{C}\right)$. Set up multiple aliquots if plating multiple plates (1 for each plate). Also have separate control tubes with just bacteria and phage.

3. Leave the Map and phagemid mixture incubating at $37^{\circ} \mathrm{C}$ overnight. At the nonpermissive temperature $\left(37^{\circ} \mathrm{C}\right)$, the phage acts as a nonlytic transducing phage for transposon delivery into Map.

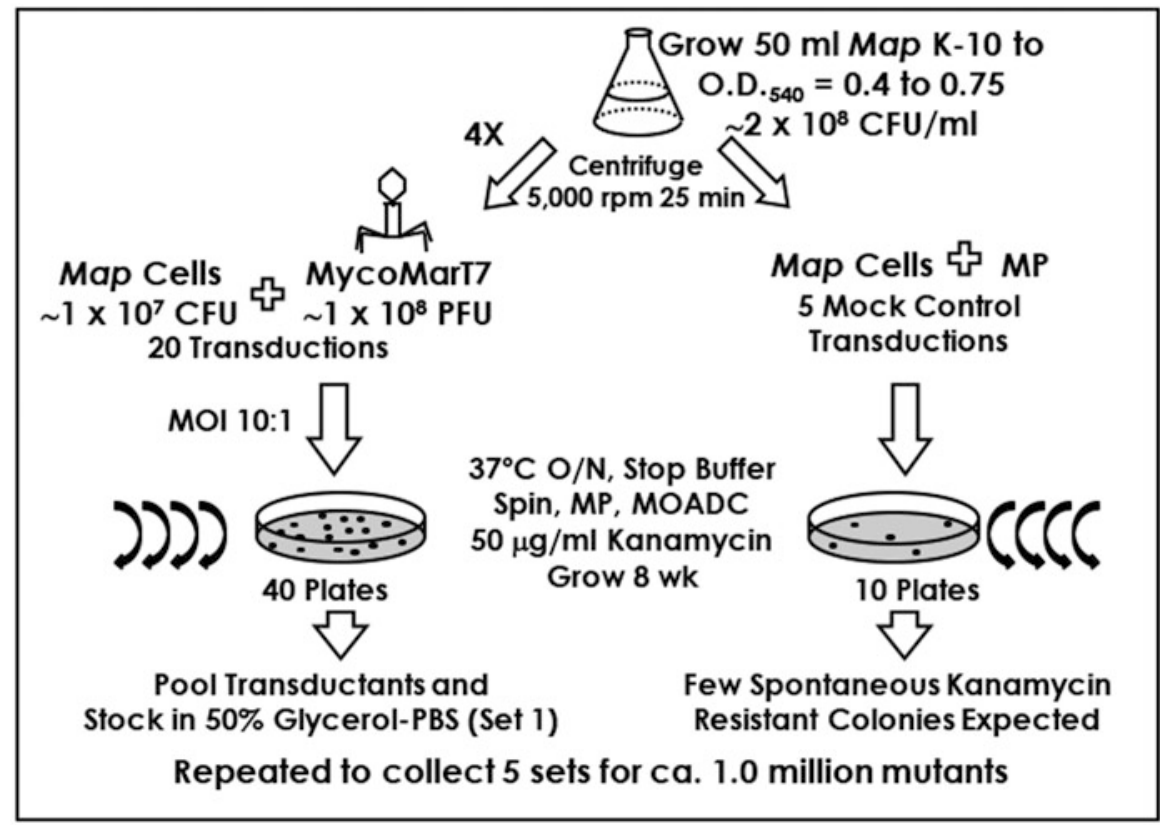

Fig. 1 Flow diagram showing the steps on how to generate a Map MycoMarT7 mutant library. The left side of the flow diagram shows the transduction sets to be pooled and stocked while the right side shows the mock transductions (without phage) to determine percentage of spontaneous kanamycin resistance 


\subsection{Plating \\ Transposon Mutants}

\subsection{Harvesting Colonies Representing Transposon Mutants}

4. Add an equal volume of stop buffer, wait $5 \mathrm{~min}$ and immediately proceed to plating in the next section.

1. Independent transductions can be performed and plated separately to obtain a collection of insertional mutants. Alternatively, colonies can be pooled from several independent transductions to obtain a highly representative insertional library.

2. Plate $0.1 \mathrm{ml}$ volumes of the stopped transduction mixture on Middlebrook $7 \mathrm{H} 10$ plates supplemented with $0.5 \%$ glycerol, $0.01 \%$ cycloheximide, $1 \mathrm{mg}$ of mycobactin J and OADC without Tween 80, but containing either $50 \mu \mathrm{g} / \mathrm{ml}$ kanamycin. Use a bent glass rod "hockey stick" or L-spreader to disperse the aliquot over the entire surface of the plate (see Note 4 ).

3. Individual kanamycin-resistant transductants are randomly picked after an 8 week incubation period at $37^{\circ} \mathrm{C}$.

4. The entire library can be harvested and stocked in 50\% glycerol-PBS freezing solution. The library can be stored in 0.5 - $\mathrm{ml}$ aliquots at $-80{ }^{\circ} \mathrm{C}$.

1. Colonies can be picked individually or harvested together depending on the goal of the experiment.

2. If picking and stocking individual colonies separately, these can be picked using a sterile needle into 96 -well plates containing Middlebrook $7 \mathrm{H} 9$ media $(0.2 \mathrm{ml})$.

3. If harvesting together, flood the plates with either MP buffer or Middlebrook $7 \mathrm{H} 9$ media and concentrate mutants by centrifugation.

4. DNA can then be extracted for Tn-seq analysis or individually stocked mutants can be screened for various phenotypic traits.

\section{Notes}

1. The ADC/OADC supplement is purchased commercially, filtered through a $0.2 \mu \mathrm{m}$ filter assembly and added to the autoclaved-sterilized Middlebrook 7H9 media. Note that $\mathrm{ADC} / \mathrm{OADC}$ is only added after the media has cooled below $50{ }^{\circ} \mathrm{C}$. Bacteriological media for plating transductions should be prepared fresh 2 days before the experiment and allowed to dry in a $37{ }^{\circ} \mathrm{C}$ incubator to prevent water accumulation from condensation. Alternatively for Middlebrook 7H9 and 7H10 media preparation, ADC/OADC can be made from scratch with additional details found in Chacon et al. [20] and Larsen et al. [21]. For the growth of M. smegmatis $\mathrm{mc}^{2} 155$ and Map $\mathrm{K}-10$, the addition of catalase and cycloheximide to these media is optional. 
2. Tween ${ }^{\mathrm{TM}} 80$ helps prevent clumping, which is not necessary when plating on solid media.

3. High titer lysates are used for propagation of phage when large amounts of phage are needed for transductions. Examples include replenishing working stocks, phage purification, or phage DNA isolation.

4. Solid media petri plates come in various sizes but the most common is $100 \mathrm{~mm} \times 15 \mathrm{~mm}\left(60 \mathrm{~cm}^{2}\right.$ area $)$ can be sealed with paraffin to prevent drying.

5. The phagemid will diffuse into the MP buffer during the overnight incubation. The plates can be kept stagnant or on a slow rocking platform. The phage soft agar will shrink at $4{ }^{\circ} \mathrm{C}$ and then expand under the $37^{\circ} \mathrm{C}$ temperature to help release the phage Larsen et al. [21].

6. Keep the mycobacteriophage in two stock vials: working stock and back-up stock. Then only use from the working stock bottles and keep the back-up vial only for repropagation of phage when the working stock is depleted or has developed a problem such as contamination.

7. All phage stocks must be kept in the refrigerator at $4{ }^{\circ} \mathrm{C}$. If the phage must be taken out of the refrigerator for any length of time, then the phage should be placed on ice. Temperature variations will cause a phage titer to decrease.

8. When using the phage stocks, extreme care must be used to prevent contamination of the stocks. We suggest wearing alcohol-rinsed latex gloves, wiping the phage stock bottle off with alcohol tissue and allowing it to dry thoroughly, using fresh sterile pipet tips every time an aliquot is taken from the phage stock bottle, and wrapping the bottle lid with paraffin before returning to $4^{\circ} \mathrm{C}$ storage.

\section{Acknowledgments}

This work was supported by the USDA-Agricultural Research Service and the USDA-National Institute of Food and Agriculture grant award 2013-67015.

\section{References}

1. Foley-Thomas EM, Whipple DL, Bermudez LE, Barletta RG (1995) Phage infection, transfection and transformation of Mycobacterium avium complex and Mycobacterium paratuberculosis. Microbiology 141(Pt 5):1173-1181

2. Harris NB, Feng Z, Liu X, Cirillo SL, Cirillo JD, Barletta RG (1999) Development of a transposon mutagenesis system for Mycobacterium avium subsp. paratuberculosis. FEMS Microbiol Lett 175(1):21-26. doi:S03781097(99)00170-6 [pii]

3. Cirillo JD, Barletta RG, Bloom BR, Jacobs WR Jr (1991) A novel transposon trap for 
mycobacteria: isolation and characterization of IS1096. J Bacteriol 173(24):7772-7780

4. Rathnaiah G, Lamont EA, Harris NB, Fenton RJ, Zinniel DK, Liu X, Sotos J, Feng Z, Livneh-Kol A, Shpigel NY, Czuprynski CJ, Sreevatsan S, Barletta RG (2014) Generation and screening of a comprehensive Mycobacterium avium subsp. paratuberculosis transposon mutant bank. Front Cell Infect Microbiol 4:144. https://doi.org/10.3389/fcimb. 2014.00144

5. Ghosh P, Wu CW, Talaat AM (2013) Key role for the alternative sigma factor, $\mathrm{SigH}$, in the intracellular life of Mycobacterium avium subsp. paratuberculosis during macrophage stress. Infect Immun 81(6):2242-2257. https://doi. org/10.1128/IAI.01273-12

6. Shippy DC, Lemke JJ, Berry A, Nelson K, Hines ME 2nd, Talaat AM (2017) Superior protection from live-attenuated vaccines directed against Johne's disease. Clin Vaccine Immunol 24(1). https://doi.org/10.1128/ CVI.00478-16

7. Chen JW, Scaria J, Chang YF (2012) Phenotypic and transcriptomic response of auxotrophic Mycobacterium avium subsp. paratuberculosis leuD mutant under environmental stress. PLoS One 7(6):e37884. https://doi.org/10.1371/journal.pone. 0037884

8. Park KT, Dahl JL, Bannantine JP, Barletta RG, Ahn J, Allen AJ, Hamilton MJ, Davis WC (2008) Demonstration of allelic exchange in the slow-growing bacterium Mycobacterium avium subsp. paratuberculosis, and generation of mutants with deletions at the $p k n G, r e l A$, and $l s r 2$ loci. Appl Environ Microbiol 74 (6):1687-1695. https://doi.org/10.1128/ AEM.01208-07. AEM.01208-07 [pii]

9. Park KT, Allen AJ, Barrington GM, Davis WC (2014) Deletion of $\mathrm{relA}$ abrogates the capacity of Mycobacterium avium paratuberculosis to establish an infection in calves. Front Cell Infect Microbiol 4:64. https://doi.org/10. $3389 /$ fcimb.2014.00064

10. Faisal SM, Chen JW, Yan F, Chen TT, Useh NM, Yan W, Guo S, Wang SJ, Glaser AL, McDonough SP, Singh B, Davis WC, Akey BL, Chang YF (2013) Evaluation of a Mycobacterium avium subsp. paratuberculosis leuD mutant as a vaccine candidate against challenge in a caprine model. Clin Vaccine Immunol 20 (4):572-581. https://doi.org/10.1128/CVI. 00653-12

11. Rathnaiah G, Bannantine JP, Bayles DO, Zinniel DK, Stabel JR, Grohn YT, Barletta RG (2016) Analysis of Mycobacterium avium subsp. paratuberculosis mutant libraries reveals loci-dependent transposition biases and strategies to novel mutant discovery. Microbiology. https://doi.org/10.1099/mic.0.000258

12. Danelishvili L, Wu M, Stang B, Harriff M, Cirillo SL, Cirillo JD, Bildfell R, Arbogast B, Bermudez LE (2007) Identification of Mycobacterium avium pathogenicity island important for macrophage and amoeba infection. Proc Natl Acad Sci U S A 104 (26):11038-11043. https://doi.org/10. 1073/pnas.0610746104.0610746104 [pii]

13. Wu CW, Livesey M, Schmoller SK, Manning EJ, Steinberg H, Davis WC, Hamilton MJ, Talaat AM (2007) Invasion and persistence of Mycobacterium avium subsp. paratuberculosis during early stages of Johne's disease in calves. Infect Immun 75(5):2110-2119. https://doi. org/10.1128/IAI.01739-06. IAI.01739-06 [pii]

14. Bannantine JP, Everman JL, Rose SJ, Babrak L, Katani R, Barletta RG, Talaat AM, Grohn YT, Chang YF, Kapur V, Bermudez LE (2014) Evaluation of eight live attenuated vaccine candidates for protection against challenge with virulent Mycobacterium avium subspecies paratuberculosis in mice. Front Cell Infect Microbiol 4:88. https://doi.org/10.3389/ fcimb.2014.00088

15. Shin SJ, Wu CW, Steinberg H, Talaat AM (2006) Identification of novel virulence determinants in Mycobacterium paratuberculosis by screening a library of insertional mutants. Infect Immun 74(7):3825-3833. https://doi. org/10.1128/IAI.01742-05. 74/7/3825 [pii]

16. Bardarov S, Kriakov J, Carriere C, Yu S, Vaamonde C, McAdam RA, Bloom BR, Hatfull GF, Jacobs WR Jr (1997) Conditionally replicating mycobacteriophages: a system for transposon delivery to Mycobacterium tuberculosis. Proc Natl Acad Sci U S A 94 (20):10961-10966

17. Sassetti CM, Boyd DH, Rubin EJ (2001) Comprehensive identification of conditionally essential genes in mycobacteria. Proc Natl Acad Sci U S A 98(22):12712-12717. https://doi. org/10.1073/pnas.231275498

18. Rubin EJ, Akerley BJ, Novik VN, Lampe DJ, Husson RN, Mekalanos JJ (1999) In vivo transposition of mariner-based elements in enteric bacteria and mycobacteria. Proc Natl Acad Sci U S A 96(4):1645-1650

19. Reddacliff LA, Nicholls PJ, Vadali A, Whittington RJ (2003) Use of growth indices from radiometric culture for quantification of sheep strains of Mycobacterium avium subsp. paratuberculosis. Appl Environ Microbiol 69 (6):3510-3516 
20. Chacon O, Bermudez LE, Zinniel DK, Chahal HK, Fenton RJ, Feng Z, Hanford K, Adams LG, Barletta RG (2009) Impairment of $\mathrm{D}$-alanine biosynthesis in Mycobacterium smegmatis determines decreased intracellular survival in human macrophages. Microbiology 155(Pt 5):1440-1450. https://doi.org/10. 1099/mic.0.024901-0
21. Larsen MH, Biermann K, Jacobs WR Jr (2007) Laboratory maintenance of Mycobacterium tuberculosis. Curr Protoc Microbiol. Chapter 10:Unit 10A 11. https://doi.org/ 10.1002/9780471729259.mcl0a01s6 